\title{
THE SOURCES OF MOISTURE IN THE SAND DUNES - THE EXAMPLE OF THE WESTERN SAHARA DUNE FIELD
}

\author{
Elwira ŻMUdZKa, Dariusz WoronKo, Maciej DŁuŻEWSKI \\ Faculty of Geography and Regional Studies, University of Warsaw, Poland \\ Manuscript received: May 30, 2014 \\ Revised version: August 4, 2014
}

ŻMUdZKa E., WORONKo D., DŁUŻEWSKi M., 2014. The sources of moisture in the sand dunes - the example of the Western Sahara dune field. Quaestiones Geographicae 33(3), Bogucki Wydawnictwo Naukowe, Poznań, pp. 199-204, 2 tables, 5 figs. DOI 10.2478/quageo-2014-0042, ISSN 0137-477X.

ABSTRACT: Climatic and meteorological conditions may limit the aeolian transport within barchans. An explanation of that issue was the main goal of the investigation held in Western Sahara dune fields located around Tarfaya and Laâyoune. Particular attention was paid to the factors causing the moisture content rising of the sand dune surface layer, which could influence the wind threshold shear velocity in the aeolian transport. The wetted surface layer of sand, when receiving moisture from precipitation or suspensions, reduces the aeolian transport, even in case of wind velocity above 4-5 $\mathrm{m} \mathrm{s}^{-1}$. Fog and dew condensation does not affect the moisture of deeper sand layers, what occurs after rainfall.

KEY WORDS: moisture, dune, Western Sahara

Address of the corresponding author: Dariusz Woronko, Faculty of Geography and Regional Studies, University of Warsaw, Krakowskie Przedmieście 30,00-927 Warszawa, Poland; e-mail: dworonko@uw.edu.pl

\section{Introduction}

Tropical and subtropical deserts, occupying about one fifth of the Earth's land surface, occur in such climatic conditions which are mostly created by stable high pressure systems unfavourable for the rainfall formation (Glennie 1987, Martyn 2000, Thomas 1997). In many places of the globe, the climate of arid areas is significantly dependent on the distance from the ocean, sea currents and topographical conditions which modify synoptic processes at the local scale. These processes are responsible for forming the moisture streams and rainfall fields (Semazzi, Sun 1997, Knippertz et al. 2003).

Dune fields in the south-western part of Morocco (Western Sahara) are located in the area characterized by relatively high air humidity (above $80 \%$ on average, Ouelehri 1992) and relatively high annual rainfall (even exceeding 250 $\mathrm{mm}$ in some areas). Such factors distinguish it from others areas with barchans occurrence. In addition, fogs and dews are also relevant sources of moisture, except precipitation.

The central part of the coast of Morocco annually receives up to $100 \mathrm{~mm}$ of rainfall. In Tantan, the annual precipitation is $89.4 \mathrm{~mm}$ and $48.6 \mathrm{~mm}$ in Laâyoune (period 1996-2013). The characteristic feature is, however, a large irregularity of the rainfall. The annual rainfall course is conditioned by the nature of the subtropical circulation. The full dry season is summer when rainfalls appear occasionally - once every few years, and they are generally relatively low. The main precipitation season is in autumn and winter (3-5 rainy days on average, and up to several days per month in 
the period from November to March). It is mainly associated with the advection of temperate latitude cyclones from the Atlantic Ocean generated in the polar front. The weather during this period may also be affected by cyclones formed over Northern Africa.

The second source of moisture - fog - is particularly efficient from December to June, providing on average about $15 \mathrm{dm}^{3} \mathrm{~m}^{-2}$ of water per day. During summer, especially in July and August, the water supply from fog is three times smaller (Marzol et al. 2011). Meteorological stations located along the Atlantic coast of Morocco, including Western Sahara, annually record about 20-30 days with fog. The actual number of foggy days in different parts of the coast may be, however, much greater. Marzol et al. (2011) showed that the number of days with fog in the southern coastal part of Morocco reaches 120 per year (2006-2010). Fog water supply varies from $23.6 \mathrm{dm}^{3} \mathrm{~m}^{-2}$ (August 2010) to $350.1 \mathrm{dm}^{3} \mathrm{~m}^{-2}$ (January 2010). Within an hour, it can be even from 2.5 to $7.1 \mathrm{dm}^{3} \mathrm{~m}^{-2}$. The relatively high content of water vapour in the air and large decreases of temperature due to the strong radiation of heat during clear nights cause the formation of the early morning advective radiation fogs over dune fields. They occur locally, in negative relief forms and they are relatively thick. In general, they disappear after the sunrise. Another phenomena which occurs in the early hours of the day is dew, which lasts till 8-9 o'clock.

Weather conditions significantly affect the moisture content of the surface layer of sand dunes, which may limit the aeolian transport, increasing the threshold wind velocity necessary to detach the grains of sand from the ground. It primarily depends on the grain size and shape, mineral composition and roughness, moisture and the inclination degree of the bedrock (Wiggs 2000). In the case of sand, it is about $4-5 \mathrm{~m} \mathrm{~s}^{-1}$ (Bagnold 1941). The wind threshold shear velocity may be, however, modified by the moisture of the surface dune deposits (Cornelis, Gabriels 2003). As demonstrated in this article, this moisture comes mainly from precipitation and atmospheric deposits. Geomorphologic effects of this process are conducted mainly to stabilize the dune material (Subramanian, Kesava-Rao 1983), and limit the aeolian transport. The surface mois- ture brings about stronger sand cohesion and an increase in the wind shear threshold velocity (Lancaster 1995). The gravimetric moisture content of $0.6 \%$ can increase twice the threshold velocity for sand fraction of $0.25-0.50 \mathrm{~mm}$. Sand material with the gravimetric moisture content of about $5 \%$ or higher cannot be transported by most of the winds occurring on the Earth (Belly 1964).

\section{Methods and meteorological background}

The data necessary to analyze the impact of moisture on the aeolian transport were derived from field measurements carried out in the south-western part of Morocco (Western Sahara) in the spring seasons of 2010 and 2012. The first series of measurements was performed on the $3^{\text {rd }}-12^{\text {th }}$ of March 2010, the second on the $25^{\text {th }}$ of February - the $1^{\text {st }}$ of March 2012. Measurements were carried out in five sample points (Fig. 1). The wind velocity was measured using the Kestrel wing anemometer. The wind directions were determined by the GPS device.

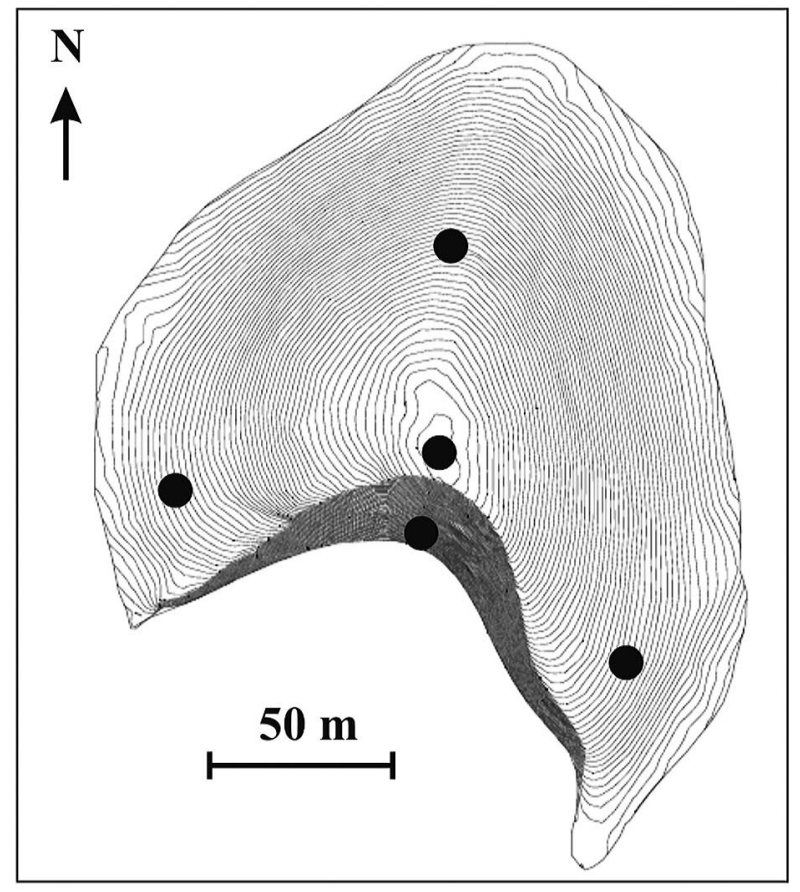

Fig. 1. The location of sample points (on the example of a dune near Laâyoune) (dune elevation model by Katarzyna Biejat) 

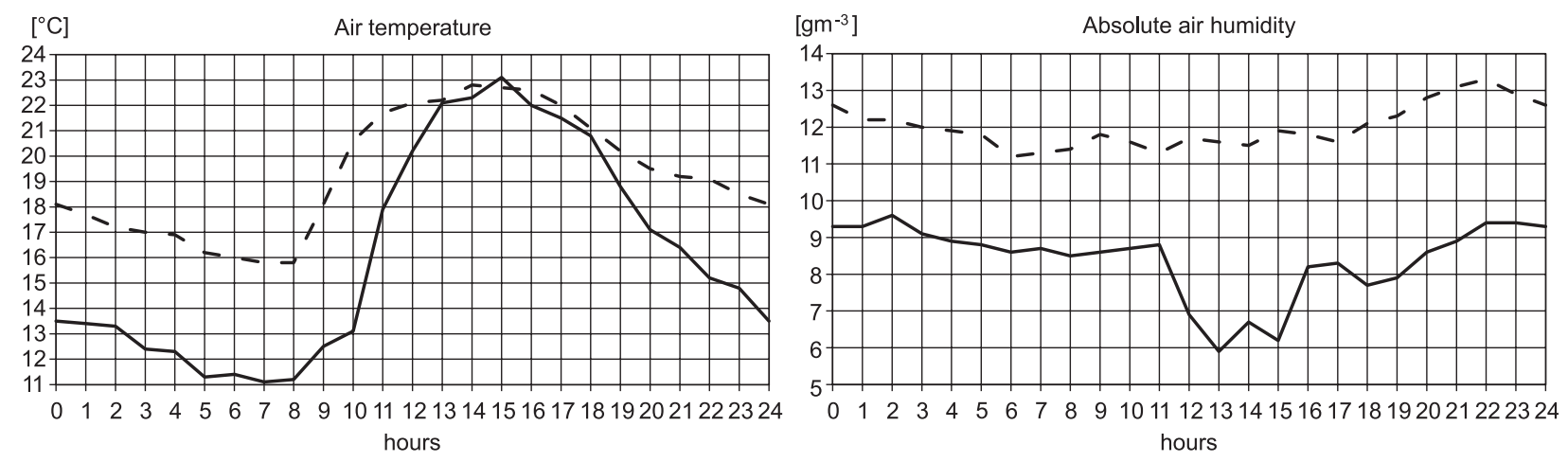

Fig. 2. The daily course of the mean air temperature and absolute air humidity in Laâyoune on 03-12.03.2010 (dashed line) and 25.02-01.03.2012 (solid line)

Moreover, the volumetric moisture content of the surface ground layer in each of the points were measured with the TDR probe. Finally, the volumetric moisture content was converted into the gravimetric moisture content. During the measurements in 2012, an attempt was made to estimate the amount of condensing water vapour on the ground surface. Cartons of the same area surfaces were used. They were weighted on the WTB 200 weight type before distributing on the dune and after collecting them.

The research study was also based on the data from the meteorological station in Laâyoune $\left(\varphi 27.15^{\circ} \mathrm{N}, \lambda 13.22^{\circ} \mathrm{W}\right)$ (www.noaa.gov; accessed 30 March 2012).

Meteorological conditions during the fieldwork measurements were typical for this season of a year, and they reflected the two most common synoptic situations of the spring. In 2010, the weather was changeable. In the early days of the measurement period the meteorological conditions were the consequence of cyclones of the Mediterranean front approaching from the west. Then they were influenced by the forming of wedge of Azores anticyclone. The weather of the last days of measurements was also affected by poorly marked low pressure systems over the north-western Africa. Low pressure systems were associated with fairly high air humidity (Fig. 2), moderate cloudiness, rainfalls and quite significant variations in the wind direction (Fig. 3). The period prior to the measurements was characterized by the presence of rather high rainfalls.

The measurements in 2012 were carried out during the sunny and cloudless days with no precipitation and the north-east wind direction in majority. The same weather conditions characterized the period preceding the measurements.
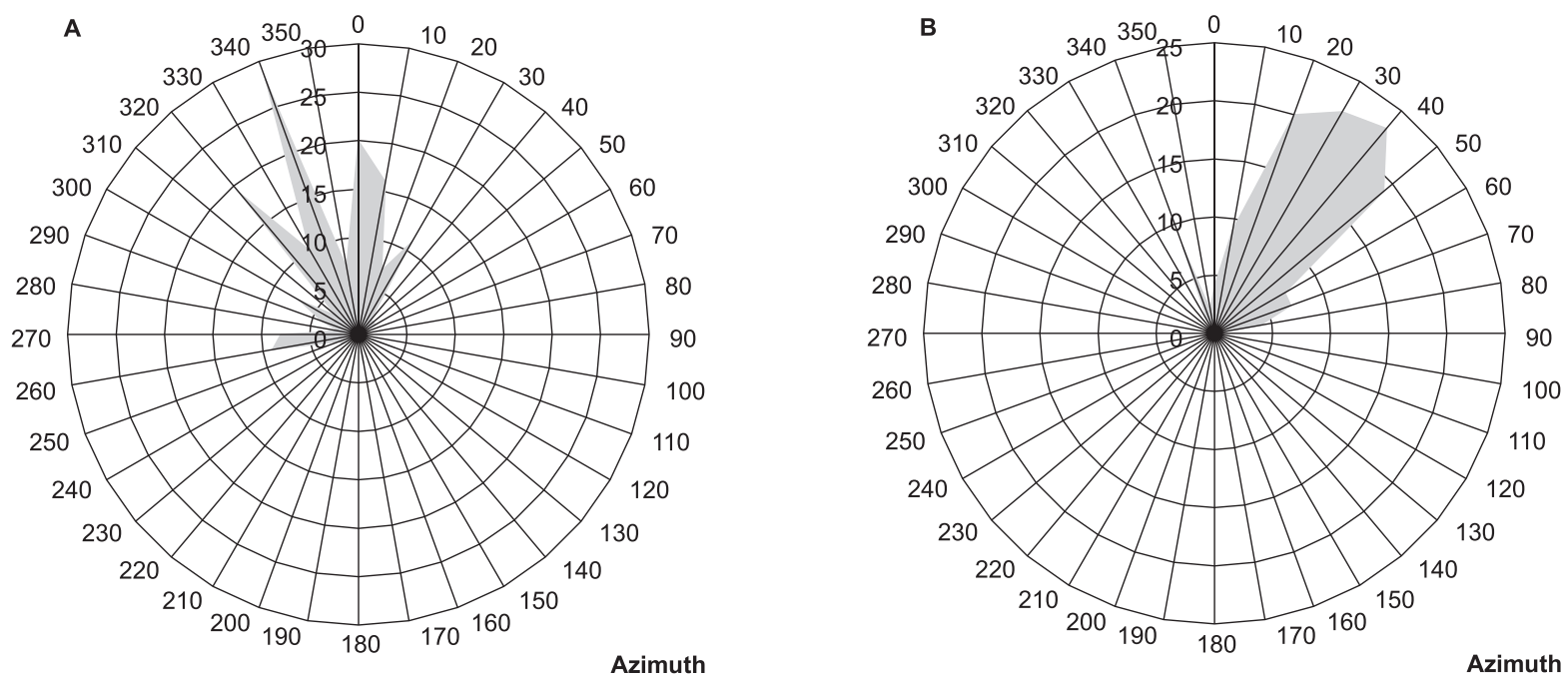

Fig. 3. Average frequency (\%) of the wind directions at the meteorological station in Laâyoune on 03-12.03.2010 (A) and 25.02-01.03.2012 (B) 
Table 1. Maximum, minimum and average values of the selected meteorological elements $(t-$ air temperature, $t_{d}$ - dew point temperature, $f$ - relative air humidity, $a$ - absolute air humidity, $E$ - saturation vapour pressure, $e$ - vapour pressure, $v$ - wind velocity) during the field measurements on 03-12.03.2010 and 25.02-01.03.2012 in Laâyoune

\begin{tabular}{|c|c|c|c|c|c|c|c|c|}
\hline Values & $\begin{array}{l}\text { Measurement } \\
\text { period }\end{array}$ & $t\left[{ }^{\circ} \mathrm{C}\right]$ & $t_{d}\left[{ }^{\circ} \mathrm{C}\right]$ & $f[\%]$ & $a\left[\mathrm{~g} \cdot \mathrm{m}^{-3}\right]$ & $E[\mathrm{hPa}]$ & $e[\mathrm{hPa}]$ & $v\left[\mathrm{~m} \cdot \mathrm{s}^{-1}\right]$ \\
\hline Maximum & \multirow{3}{*}{ 03-12.03.2010 } & 23.9 & 17.8 & 100 & 15.2 & 29.6 & 20.4 & 9.3 \\
\hline Minimum & & 13.9 & 10.0 & 50 & 9.4 & 15.9 & 12.3 & 0.0 \\
\hline Average & & 19.1 & 13.9 & 73 & 12.0 & 22.4 & 16.0 & 4.7 \\
\hline Maximum & \multirow{3}{*}{ 25.02-01.03.2012 } & 25.0 & 12.2 & 90 & 10.8 & 31.7 & 14.3 & 10.8 \\
\hline Minimum & & 6.1 & -3.9 & 14 & 3.4 & 9.4 & 4.6 & 1.0 \\
\hline Average & & 15.9 & 8.2 & 65 & 8.4 & 18.7 & 11.1 & 5.7 \\
\hline
\end{tabular}

The weather of the region was mainly modulated by the large wedge of Azores anticyclone. The air moisture content was lower than during the measurements in 2010, and the range of daily temperature was higher, mainly due to the strongly marked minimum of temperature in the early morning hours (e.g. 26 February 2012, the minimum temperature was $6.1^{\circ} \mathrm{C}$ and maximum $25^{\circ} \mathrm{C}$, Table 1).

\section{Data analysis}

Rainwater can dampen the ground layer up to even the thickness of several tens of centimetres (Dłużewski et al. 2012). That situation may persist even few days after the rainfall. Meteorological conditions during both research periods (2010 and 2012) clearly influenced the moisture of the subsurface layers of the sand dune. The moisture

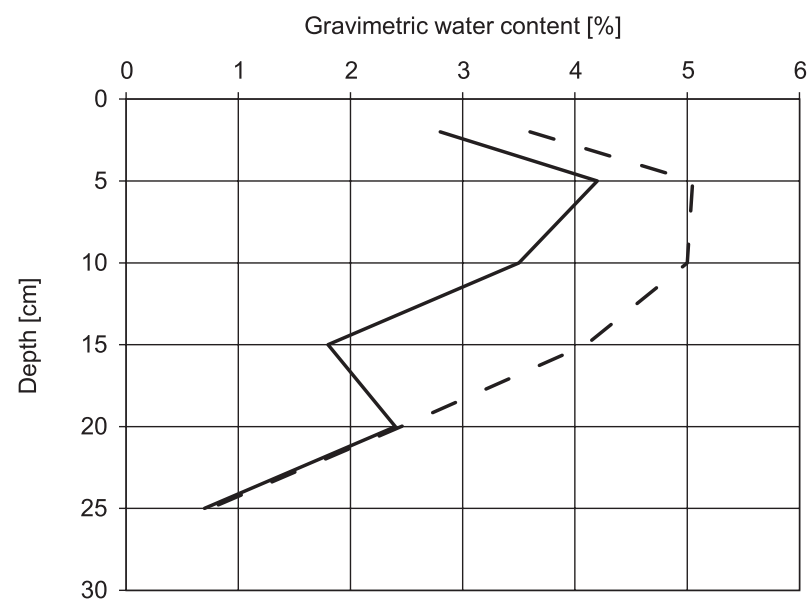

Fig. 4. The sand gravimetric water content changes with depth in deposits at 1200 o'clock, on the example of the western horn of the dune near Laâyoune $\left(\varphi 27^{\circ} 21^{\prime} 50.8^{\prime \prime} \mathrm{N}\right.$ and $\left.\lambda 13^{\circ} 07^{\prime} 44.1^{\prime \prime} W\right)$. Dashed line - 04.03.2010, solid line 11.03.2010 content measurements made in the spring of 2010 were performed after rainfalls, which resulted in relatively deep dampening of dune sands, up to more than $20 \mathrm{~cm}$ below the surface (Fig. 4).

The moisture content of the dune surface was also heightened (Table 2) and in some cases it reached $5 \%$ of the gravimetric water content, measured in the surface layer of the sand dunes (0-10 cm depth). These results confirm the measurements analyses from other dune fields, when the prior rainfalls led to dampening of the surface and subsurface sand layers up to tens of centimetres (Yair et al. 1997).

The moisture content of the sand dune measured in 2012 was different comparing to the one from 2010. It only was limited to about one centimetre of the sand layer and decayed till 10 o' clock. The gravimetric water content of the surface sand layer $(0-10 \mathrm{~cm})$ did not exceed $0.3 \%$ and was not spatially varied within the dune. Similar values of the moisture content were documented in other desert areas of the world dune deposits in conditions without precipitation events (Berndtsson et al. 1996).

Two measurement series (29 February and 1 March 2012) of the amount of condensing water vapour on a dune surface (five points within the dunes, Fig. 1) show the income of water is in

Table 2. The gravimetric water content of the subsurface layer $(0-10 \mathrm{~cm})$ in the dune sand near Laâyoune at 12:00 o'clock ( $\varphi 27^{\circ} 21^{\prime} 50.8^{\prime \prime} \mathrm{N}$ and $\left.\lambda 13^{\circ} 07^{\prime} 44.1^{\prime \prime} \mathrm{W}\right)$

\begin{tabular}{|l|c|c|}
\hline \multirow{2}{*}{$\begin{array}{c}\text { Measurement sites } \\
\text { (acc. to Fig. 1) }\end{array}$} & \multicolumn{2}{|c|}{ Gravimetric water content [\%] } \\
\cline { 2 - 3 } & 04.03 .2010 & 11.03 .2010 \\
\hline Eastern horn & 1.6 & 2.2 \\
\hline Windward slope & 2.8 & 2.6 \\
\hline Western horn & 3.7 & 3.2 \\
\hline Crest & 1.7 & 1.0 \\
\hline Lee slope & 2.7 & 1.8 \\
\hline
\end{tabular}




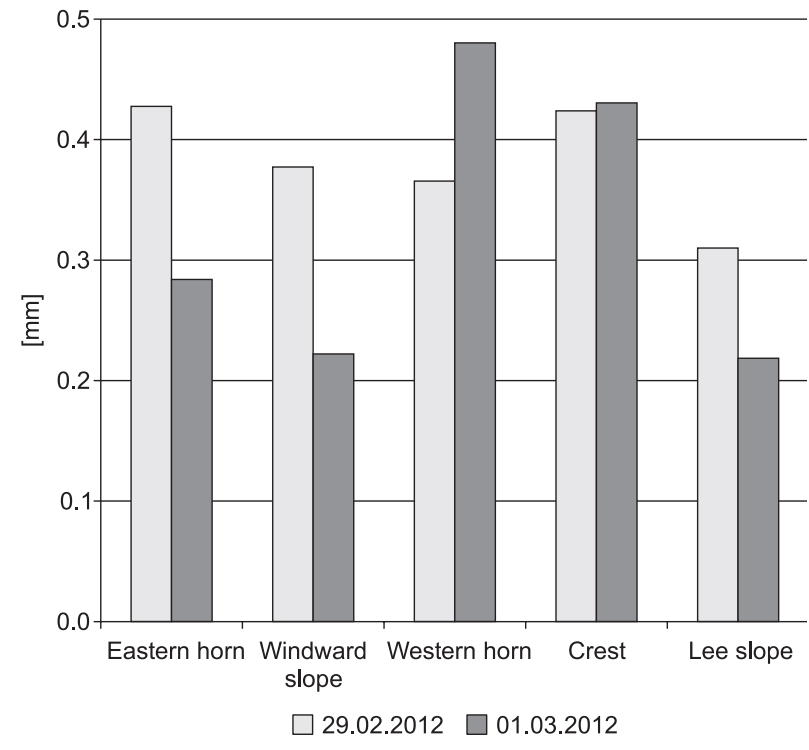

Fig. 5. The amount of condensing water from atmospheric deposits $[\mathrm{mm}]$ on the dune near Laâyoune $\left(\varphi 2^{\circ} 21^{\prime} 50.8^{\prime \prime} \mathrm{N}\right.$ and $\left.\lambda 13^{\circ} 07^{\prime} 44.1^{\prime \prime} \mathrm{W}\right)$ in the days 29.02. and 01.03.2012

the range from 0.2 to $0.5 \mathrm{~mm}$ (Fig. 5). Totally, the supply from condensing water is comparable or perhaps even exceeds the amount of water from rainfall in the area. The volume of condensing water on the surface of the dunes varied spatially. The relatively high moisture content was found on the western dune horn and its crest. The presence of fog and dew does not affect the moisture of the deeper sand layers, what occurs after the rainfall. The surface sand deposits on the eastern horn were dried out firstly, as a result of the sunlight acting.

The measurements of wind velocity have shown that in the case of a moist soil the velocities of 4-5 $\mathrm{m} \mathrm{s}^{-1}$ do not cause the initiation of the aeolian transport, which is forming only after the drying out of the surface layer of the sand dunes.

\section{Conclusion}

Barchans of Western Sahara are located in the climatic zone with the prevailing wind directions from the northern sector, which determines the spatial orientation of the dunes, as well as the supply of moisture from the Atlantic Ocean. Throughout the year, the relative air humidity is high (about $80 \%$ ), resulting from interaction of many factors. The main are the advection of air masses from the Atlantic Ocean cold current area and the radiation of heat from the ground during cloudless nights, evidenced by significant air temperature dropping during early morning hours, just before the sunrise. These factors are also responsible for the formation of fogs within the dune fields and the condensation of water vapour on the dune surface. The frequency of those processes can be even more than a hundred days a year. The results of this investigation have confirmed that the water supply from fogs and dews is comparable to or even exceeds the amount of water from rainfall in the area. The moist surface sand layer reduces the aeolian transport, even in the case of wind velocities higher than $4-5 \mathrm{~m} \mathrm{~s}^{-1}$ and may cause the asymmetry of dunes. The western horn, usually moister, is shorter than the eastern horn. The occurrence of fog and dew does not affect the moisture of the deeper sand layers, what occurs after the precipitation event. Rainwater may damp the deposits up to the depth of tens of centimetres, as demonstrated in the measurement results from the spring of 2010. Such situation may persist for several days after the rainfall event and have a significant influence on reducing the aeolian transport.

\section{References}

Bagnold R.A., 1941. The Physics of Blown Sand and Desert Dunes. Chapman \& Hall, London.

Belly P.Y., 1964. Sand Movement by Wind. Technical Memorandum 1, Addendum III. US Army Corps of Engineers, Coastal Engineering Research Center, Washington, DC.

Berndtsson R., Nodomi K., Yasuda H., Persson T., Chen H., Jinno K. 1996. Soil water and temperature patterns in arid desert dune sand. Journal of Hydrology 185: 221-240.

Cornelis W.M., Gabriels D., 2003. The effect of surface moisture on the entrainment of dune sand by wind: an evaluation of selected models. Sedimentology 50: 771-790. DOI: 10.1046/j.1365-3091.2003.00577.x

Dłużewski M., Żmudzka E., Woronko D., Biejat K., 2012. Źródło wilgoci w barchanach Sahary Zachodniej (The source of moisture in barchans of Western Sahara). Prace i Studia Geograficzne 49: 47-48.

Glennie K.W., 1987. Desert sedimentary environments, past and present - a summary. Sedimentary Geology 50: 135166.

Knippertz P., Fink A. H., Reiner A., Speth P., 2003. Three Late Summer/Early Autumn Cases of Tropical-Extratropical Interactions Causing Precipitation in Northwest Africa. Monthly Weather Review 131: 116-135. DOI: http://dx. doi.org/10.1175/1520-0493(2003)131<0116:TLSEAC $>2.0$. $\mathrm{CO} ; 2$

Lancaster N., 1995. Geomorphology of desert dunes. Routledge, London.

Martyn D., 2000. Klimaty kuli ziemskiej (Climates of The Earth). Wydawnictwo Naukowe PWN, Warszawa. 
Marzol Ma.V., Sánchez J.L., Yanes A., 2011. Meteorological patterns and fog water collection in Marocco and the Canary Islands. Erdkunde 65: 291-303. DOI: 10.3112/erdkunde.2011.03.06

Oulehri T., 1992. Étude géodynamique des migrations de sables éoliens dans la région de Laâyoune (Nord du Sahara marocain) (Geodynamic study of aeolian sand migration in the region of Laâyoune (North Sahara of Morocco). Thése de doctorat, l'Université Paris VI, Paris.

Semazzi, F.H.M., Sun L., 1997. The role of orography in determining the Sahelian climate. International Journal of Climatology 17: 581-596. DOI: 10.1002/(SICI)10970088(199705)17:6<581::AID-JOC134>3.0.CO;2-E

Subramanian A.R., Kesava-Rao A.V.R., 1983. Dew fall in sand dune areas of India. International Journal of Biometeorology 27: $271-280$.
Thomas D.S.G., 1997. Arid environments: their nature and extent. In: Thomas D.S.G. (ed.), Arid Zone Geomorphology. Process, Form and Change in Drylands. John Wiley \& Sons, Chichester: 3-12.

Wiggs G.F.S. 2000. Sediment mobilisation by the wind. In: Thomas D.S.G. (ed.), Arid Zone Geomorphology. Process, Form and Change in Drylands. John Wiley \& Sons, Chichester: 351-372.

Yair A., Lavee H., Greister N., 1997. Spatial and temporal variability of water percolation and movement in a system of longitudinal dunes, Western Negev, Israel. Hydrological Processes 11: 43-58. DOI: 10.1002/(SICI)10991085(199701)11:1<43::AID-HYP402>3.0.CO;2-D 